\title{
NATURAL GAS DEREGULATION IN BRITISH COLUMBIA: A 1987 PERSPECTIVE
}

\author{
MARK M. MOSELEY*
}

\begin{abstract}
This paper reviews the current status of natural gas deregulation in British Columbia, focussing on certain topical issues. It addresses the future role of the British Columbia Petroleum Corporation, the future role of Westcoast Transmission Company Limited, recent developments with respect to bypass initiatives and, lastly, the new British Columbia natural gas surplus determination procedures.
\end{abstract}

\section{INTRODUCTION}

Albertans, and other "easterners" who live on the inland side of the Rocky Mountains, have long regarded British Columbia as a lotus-land with its own slightly bizarre customs and practices. To a certain extent, those engaged in the natural gas industry share this perspective, believing that a variety of mysterious arrangements exist in British Columbia in respect of exploring, producing, transporting and marketing natural gas.

In fact, many of these differences are more apparent than real. In a number of instances, they are caused by geology and geography, rather than by politics or public policy. Certainly, with respect to the current policy shift towards deregulation of the natural gas industry, the Province of British Columbia ("the Province") is on record as being as committed as any government in Canada.

This paper will attempt to provide a status report on certain current natural gas deregulation issues in British Columbia. It does not, however, purport to be an exhaustive treatment of the subject. Instead, the focus of attention will be on four particular areas. These consist of the future of the British Columbia Petroleum Corporation ("the BCPC"), the future of Westcoast Transmission Company Limited ("Westcoast"), recent developments with respect to bypass and, lastly, the new British Columbia natural gas surplus determination procedures. The discussion of these four topics is preceded by the following section which briefly provides some background information concerning the deregulation of the natural gas industry to date in British Columbia.

Before proceeding, two additional points should be made.

Firstly, this paper suffers, in extremis, from the problems associated with hitting a very fast-moving target. During 1987, a great many changes are taking place and it is impossible to give a single "snap-shot" description which will remain valid for any length of time. Accordingly, readers are advised that this paper discusses developments as they exist as of mid-July, 1987.

The second matter which must be noted relates to the authorship of this paper. Although the writer has, on occasion, acted for the British Columbia Ministry of Energy, Mines and Petroleum Resources and for the BCPC, this paper is not, in any way, to be construed as an expression of the views of the Province or any of its Ministries or crown corporations. The opinions expressed herein are solely those of the author as a private citizen.

- Partner, Guild, Yule \& Company, Vancouver, British Columbia. 
[VOL. XXVI, NO. 1

\section{BACKGROUND}

There are two seminal documents with respect to natural gas deregulation in British Columbia.

The first is a "Report on the Marketing of British Columbia Natural Gas", ${ }^{1}$ which was released by the Province in September, 1983 ("the 1983 Govier Report"). This document was prepared by a four member Study Group, chaired by Dr. G. W. Govier, which was asked to examine the structure of the natural gas industry in British Columbia and to recommend changes to stimulate exploration, development and marketing. When the 1983 Govier Report was released, the Province announced that it was prepared to accept virtually all of the recommendations made therein, including measures which had the effect of significantly deregulating the industry in British Columbia.

In addition to establishing the opening framework for deregulation, the 1983 Govier Report is also useful in that it described, in considerable detail, the features of the industry in British Columbia and how they differed from the arrangements in the other two natural gas producing provinces, Alberta and Saskatchewan. Indeed, the entire second section of the 1983 Govier Report consists of a comparative analysis of how the three provinces treated matters such as the disposition of natural gas rights, royalties, taxes, pricing, incentives and similar items. Accordingly, even though the information is now somewhat out of date, the 1983 Govier Report is a very helpful starting point for those who wish to understand the recent history of the natural gas industry in British Columbia.

At the time of the public release of the 1983 Govier Report, the Province issued a separate document entitled "Decisions and Comments" out its responses to the recommendations. In that document, the Province indicated that it wished to receive additional comments from interested parties on certain of the issues raised in the 1983 Govier Report. This, in turn, lead to the release by the Province, in July 1984, of a paper entitled "Final Decisions and Comments". It was in this latter document that the Province in effect committed itself to a policy of deregulation whereby there would be a "reduction of government participation in the marketing system to encourage more competitive and aggressive marketing".

The next step in this process was the passage of the Natural Gas Price Act. ${ }^{4}$ This legislation, along with various amendments to pre-existing statutes, permitted natural gas producers in British Columbia to make direct sales to virtually any buyer instead of having to deal only with the BCPC. In short, the BCPC became a non-exclusive marketer of natural gas, as recommended in the 1983 Govier Report. Concomitant with this was a change to a system whereby royalties would be paid directly by

1. British Columbia, "Report of the Study Group on the Marketing of British Columbia Natural Gas" chaired by Dr. G. W. Govier (1983).

2. British Columbia, "Report on the Marketing of British Columbia's Natural Gas: Decisions and Comments" (1983).

3. British Columbia, "Report on Marketing of British Columbia's Natural Gas: Final Decisions and Comments" (1984) at 2.

4. S.B.C. 1985 , c. 53. 
producers instead of being collected indirectly by the BCPC, again pursuant to a recommendation in the 1983 Govier Report.

Throughout this process, however, the Province made it clear that it would not unilaterally abrogate existing contracts, including the contracts between producers and the BCPC. To this extent, the new marketing arrangements were confined to "future contracted gas" as defined in the 1983 Govier Report.

The second major document with respect to natural gas deregulation in British Columbia is, of course, the October 31, 1985 Agreement Among the Governments of Canada, Alberta, British Columbia and Saskatchewan on Natural Gas Markets and Prices ("the October 31, 1985 Agreement")."

As one of the four signatories to the October 31, 1985 Agreement, the Province committed itself to a variety of measures designed to facilitate the transition to a "more flexible and market-oriented pricing regime", particularly with respect to natural gas in interprovincial trade. In addition, the Province also committed itself to reviewing the British Columbia natural gas surplus determination procedures, as discussed in Section VI of this paper.

As indicated, the October 31, 1985 Agreement dealt with the establishment, within one year, of market sensitive pricing for natural gas in interprovincial trade. It did not address intraprovincial sales. However, in June of 1986, the Province nevertheless announced that it also intended to deregulate the price of natural gas produced and sold within British Columbia, to the extent that it would cease to establish the downstream wholesale prices paid by the local distribution utilities to Westcoast. Instead, as of November 1, 1986, prices were to be established by negotiations between the distribution utilities, Westcoast and the BCPC, as discussed in the following section of this paper.

\section{THE FUTURE OF THE BCPC}

When it was established in 1973, the BCPC became the sole purchaser of natural gas from producers in British Columbia. All of the existing contracts between Westcoast and the producers were novated to the BCPC. At the time of writing, the BCPC is purchasing natural gas from over 140 producers, pursuant to some 750 contracts, some of which extend beyond the year 2000 .

All of the natural gas which BCPC purchases is immediately resold at the wellhead to Westcoast. Westcoast in turn processes and transports this natural gas and then sells to the local distribution utilities in British Columbia and to the export market. The "Basic Agreement", which is the contract between Westcoast and the BCPC, commits the BCPC to supplying all of the natural gas necessary to meet Westcoast's existing domestic and export obligations. This includes all of the natural gas sold by Westcoast to the local distribution utilities under contracts which last until 1991.

5. The text of the October 31, 1985 Agreement is published in Canada Energy Law Service, Hunt et al Editors, Canadian Institute of Resources Law, Richard De Boo Publishers, Volume II at 30-1806 et. seq. 
Between 1973 and 1985, the Province established the wholesale prices paid by the local distribution utilities to Westcoast. From the revenues thereby received, Westcoast would deduct its cost of service as authorized by the National Energy Board ("NEB") and remit the difference to the BCPC. For natural gas flowing to the export market, Westcoast would similarly deduct its authorized cost of service and remit the appropriate amounts to the BCPC and out-of-province producers. The BCPC would then pay British Columbia producers a deemed field price with various adjustments. The difference between the amounts received by the BCPC and the amounts paid to producers constituted the "economic rent" which was charged in lieu of royalties. This fund was then remitted by the BCPC to the Province.

When the Natural Gas Price Act ${ }^{6}$ was passed in 1985, producers began to pay a direct royalty. The BCPC only deducted its own administrative cost of service charge and the entirety of the balance went to producers. However, downstream wholesale prices paid by the local distribution utilities to Westcoast were still being set by the Province. As noted in the preceding section, the Province subsequently announced, on June 13, 1986 , that, as of November 1 of that year, the prices of all natural gas sold in British Columbia would be "determined by negotiations between buyers and sellers".' At the same time, the then Minister of Energy, Mines and Petroleum Resources stated that "we are steadily moving B.C. gas policy towards our final goal - a minimum of government intervention and a maximum of freedom for the private sector to operate". ${ }^{8}$ However, the new arrangements still left the BCPC as one of the participants in the negotiation of the wholesale prices.

The next step in the deregulation process was the release by the Province, on January 21, 1987, of the Columbia-Pacific Group Report entitled "B.C.P.C. Under Natural Gas Deregulation: Preliminary Review, Evaluation and Recommendations", authored by Mr. D. W. Ross (the "1987 Ross Preliminary Report"). ${ }^{9}$ In the covering letter which was sent to interested parties in the British Columbia natural gas industry, the current Minister of Energy, Mines and Petroleum Resources, the Honourable J. Davis, indicated that the 1987 Ross Preliminary Report was being circulated to elicit comments as to the future role of the BCPC. This was described as part of a further step in realizing "the benefits of a market-oriented system".

The 1987 Ross Preliminary Report raised a number of concerns with respect to the role of the BCPC. It examined the recent record of the BCPC in negotiating the wholesale prices which had been established as of November 1, 1986. It also commented on the other marketing activities of the BCPC and on its administrative and regulatory functions. The 1987 Ross Preliminary Report stated that certain parties in the natural gas industry had expressed concerns as to the appropriateness of any market-

6. Supran. 4.

7. British Columbia, Ministry of Energy, Mines and Petroleum Resources News Release, "B.C. Natural Gas Prices Heading for Deregulation" 1986:24.

8. Id.

9. Columbia-Pacific Group, “B.C.P.C. Under Natural Gas Deregulation: Preliminary Review, Evaluation and Recommendations" (1986). 
ing role for the BCPC. In particular, there was a perception that the BCPC was in a position of conflict of interest in that its administrative function in monitoring transactions under the Natural Gas Price Act $^{10}$ may give it information which it could advantageously use as a non-exclusive marketer. Finally, concerns were also expressed as to the appropriate future activities of the BCPC as an intervener in hearings before the NEB respecting the rates of Westcoast and other matters.

Interested parties were given until February 20, 1987, to submit comments on the Ross Preliminary Report and a number of companies and associations chose to do so.

Although no formal announcements have subsequently been made, it is apparent that the Province still has this issue under consideration. For example, the Honourable J. Davis has been quoted in the press" as saying that the BCPC, at least in its present guise, will ultimately be eliminated but that the timing was uncertain due to the long term contracts with producers. Clearly, the Province is looking for some sort of change to the BCPC without unilaterally abrogating the existing contracts. One of the options which likely is under consideration is some form of privatization, whereby the BCPC may become an agent on behalf of its producers. Naturally, as the year develops, this process of change should become more apparent, particularly by the time that parties have to negotiate the new 1987-88 wholesale prices. The future of the BCPC is, in short, a prime example of a natural gas deregulation issue which is continuing to evolve in British Columbia.

\section{THE FUTURE OF WESTCOAST}

Amongst the more controversial recommendations in the 1983 Govier Report were those dealing with the future of Westcoast. Of particular interest were the recommendations concerning provincial regulation of Westcoast's intraprovincial activities and the separation of Westcoast's marketing and transportation functions.

In its "Decisions and Comments" paper, ${ }^{12}$ the Province accepted the recommendation that negotiations should begin to place Westcoast's intraprovincial activities under provincial, as opposed to NEB, regulation. As noted in the 1983 Govier Report, there was no reason in principle why these activities should not be subject to provincial jurisdiction, as is the case with NOVA, AN ALBERTA CORPORATION. Subsequently, in the "Final Decisions and Comments" paper, ${ }^{13}$ the Province also accepted the recommendation that Westcoast should continue to be a non-exclusive marketer of British Columbia natural gas. However, this was accepted on the basis that its marketing functions should be clearly separate from the transportation and processing functions. The objective in this regard was to create a system whereby Westcoast would be obliged to provide the services of a common carrier at competitive rates.
10. Supra n. 4.
11. The Sun (Vancouver), "Gas deregulation to go on, says Davis" 14 February 1987 at D-13.
12. Supra n. 2 at 6.
13. Supra n. 3 at 11. 
[VOL. XXVI, NO. 1

These decisions were subsequently acted upon in terms of representations made by the Province to the Pipeline Review Panel and to the NEB.

In its March 18, 1986 submission to the Pipeline Review Panel, ${ }^{14}$ the Province reiterated its views with respect to the separation of Westcoast's marketing functions from the utility operation. Furthermore, in a supplementary submission dated April 30, 1986, ${ }^{\text {is }}$ the Province quoted from the 1983 Govier Report to indicate that it would be: ${ }^{16}$

Investigating ways and means, including seeking the advice and cooperation of Westcoast, the NEB, the federal government and any other concerned party to bring Westcoast's activities in gathering, processing and transporting British Columbia gas within the province under provincial control.

In response, the Pipeline Review Panel, in its Review, ${ }^{17}$ recommended the separation of the marketing and transportation functions of pipeline companies $^{18}$ and it endorsed the plan of the Province to bring Westcoast's intraprovincial activities under provincial jurisdiction. ${ }^{19}$

In the context of recent NEB hearings, the issue of separating Westcoast's functions has received considerable attention. In the August 1986 Reasons for Decision in respect of the 1986 Westcoast Toll Application, the NEB noted that: ${ }^{20}$

While the establishment of a "division" within the present corporate structure would be acceptable, the Board would prefer a more fundamental corporate reorganization wherein the marketing organization would be established as a separate corporate body, owned by a holding company which would also own the utility company as a separate corporation.

The Board appreciates that such a far-reaching reorganization may or may not be desirable from Westcoast's point of view.

This statement was affirmed in the April 1987 Reasons for Decision in respect of the 1987 Export Interruptible Sales Toll Application, wherein the NEB noted that:21

Again, the Board wishes to reinforce the distinction between Westcoast, the marketer, and Westcoast, the transporter.

Obviously, pressure is being applied on Westcoast to adopt a new structure, perhaps similar to that employed by TransCanada PipeLines Limited ("TransCanada") in creating Western Gas Marketing Limited. Conceivably, Westcoast's transportation and processing subsidiary, or at least its

14. British Columbia, "Submission of the Government of British Columbia to the Pipeline Review Panel (Established under the Agreement on Natural Gas Markets and Prices, October 31, 1985)" 18 March 1986.

15. British Columbia, "Supplementary Submissions of the Government of British Columbia to the Pipeline Review Panel (Established under the Agreement on Natural Gas Markets and Prices, October 31, 1985)" 30 April 1986.

16. Id. at 2.

17. Pipeline Review Panel, "Review of the Role and Operations of Interprovincial and International Pipelines in Canada Engaged in the Buying, Selling and Transmission of Natural Gas" June 1986.

18. Id. at 12.

19. Id. at 30.

20. National Energy Board, "Reasons for Decision, With respect to the 1986 Toll Application of Westcoast Transmission Company Limited: Order RH-6-85" August 1986, published by the Minister of Supply and Services Canada, 1986, as Cat. No. NE22-1/1986-8E at 72.

21. National Energy Board, "Reasons for Decision, With Respect to the Export Interruptible Sales Toll of Westcoast Transmission Company Limited: Order RH-1-87" April 1987 at 4. 
intraprovincial component, might then also have its tolls regulated provincially. Westcoast itself has recognized this pressure in that it has stated, under cross-examination during NEB proceedings, that it is examining the question of establishing separate corporate entities for this purpose. Furthermore, the latest Westcoast Annual Report acknowledges that:22

Insofar as deregulation is concerned, the elimination of government administered pricing in Canada and the new requirements that transmission pipelines provide a pure transportation function as well as their traditional middleman function of gas buyer and seller, present problems and risks for Westcoast.

Notwithstanding this recognition, however, a great many steps have yet to be taken before the role of Westcoast in this new deregulated environment becomes clear.

\section{BYPASS INITIATIVES}

The prospect of a "bypass" of a local distribution utility, whereby an industrial direct purchaser would build its own pipeline to connect its plant with the Westcoast transmission mainline, is a relatively recent development in British Columbia.

Prior to 1987, the Province was clearly opposed to such arrangements. In the aforementioned "Decisions and Comments" paper, which approved direct sales to industries, it was stated that: ${ }^{23}$

Direct sales may be made to eligible purchasers but only through the facilities of the appropriate utility company.

Of course, a number of events subsequently took place on the national scene to promote the prospect of bypass. Firstly, there was the release of the Pipeline Review Panel's Review which specifically asserted that customers should have the option of constructing their own bypass facilities if there was to be "a truly market-competitive system". ${ }^{24}$ This was, in turn, followed by the NEB December 1986 Reasons for Decision in respect of the 1986 Cyanamid Canada Pipeline Inc. Facility Application. ${ }^{25}$

These developments, along with the prospect of significant energy cost savings, led three British Columbia companies to apply to the provincial Minister of Transportation and Highways for leave to construct bypass pipelines. On February 23, 1987, Prince George Pulp and Paper Limited ("Prince George Pulp") and Husky Oil Operations Limited ("Husky Oil") jointly applied, pursuant to section 11 of the Pipeline Act, ${ }^{26}$ for leave to construct a $6.8 \mathrm{~km}, 168 \mathrm{~mm}$ diameter pipeline connecting the facilities of Westcoast to the plants of the two companies. On March 16, a similar application was made by Northwood Pulp and Timber Limited ("Northwood") for leave to construct a $7 \mathrm{~km}, 168 \mathrm{~mm}$ diameter pipeline. Each of these two pipelines would bypass the local distribution system of

22. Westcoast Transmission Company Limited, "Annual Report 1986" (1987) at 4.

23. Supran. 2 at 8.

24. Supran. 17 at 14.

25. National Energy Board, "Reasons for Decision, In the Matter of an Application Under Section 49 and Subsection 59(3) of the National Energy Board Act of Cyanamid Canada Pipeline Inc." December 1986, published by the Minister of Supply and Services Canada, 1986, as Cat. No. NE22-1/1986-14E.

26. R.S.B.C. 1979 , c. 328. 
Inland Natural Gas Co. Ltd. ("Inland") and both applications indicate that the payback periods, under moderately favourable conditions, could be less than three years.

The Province's response to the policy issues raised by these two applications was set out in a Ministry of Energy, Mines and Petroleum Resources News Release dated March 19, 1987. ${ }^{27}$ In that document, it was stated that deregulation implied that industries now had a choice of buying directly from a producer or of building their own bypass facilities. However, the Province wished to retain jurisdiction over such bypass facilities, and, for this reason, it had decided to designate all such bypass pipelines, regardless of size, as "regulated projects" pursuant to section 16 of the Utilities Commission Act. ${ }^{28}$ This was done pursuant to Order in Council No. 552, which came into force the same day as the announcement, March 19, 1987.

This designation of bypass pipelines as regulated projects was obviously designed to respond to the legal controversy surrounding the jurisdiction over the aforementioned proposed Cyanamid Canada Pipeline Inc. bypass in Ontario. In its Reasons for Decision concerning that facility, the NEB stated that, since the proposed pipeline would be connected to the interprovincial TransCanada system, it came under the federal jurisdiction exercised by the NEB. ${ }^{29}$ However, the Ontario Energy Board ("OEB") took a different view of the matter ${ }^{30}$ and referred the jurisdictional question to the Divisional Court of the High Court of Justice of Ontario. In its judgment handed down on March 26, 1987, in Ontario Energy Board v. Consumers' Gas Company Ltd. et al, this Court ruled in favour of provincial jurisdiction, upholding the position of the OEB. ${ }^{31}$ In turn, this matter has now been appealed to the Ontario Court of Appeal by way of a stated case and the NEB has taken steps to refer its decision to the Federal Court of Appeal.

In view of the Province's designation of these pipelines as "regulated projects", both of the British Columbia bypass proponents have now also applied, as of May 1 and 4, 1987, to the Minister of Energy, Mines and Petroleum Resources for Energy Project Certificates under the Utilities Commission Act. ${ }^{32}$ This Act provides that a public hearing may be held by the British Columbia Utilities Commission ("BCUC") to deal with such applications and, in a subsequent Ministry of Energy, Mines and Petroleum Resources News Release dated June 11, 1987, it was announced that Mr. Vern Millard had been appointed as a temporary commissioner of the BCUC for this purpose. ${ }^{33}$

27. British Columbia, Ministry of Energy, Mines and Petroleum Resources News Release, "Province Declares Jurisdiction in Pipeline Bypass Issue" 1987:10.

28. S.B.C. 1980 , c. 60 .

29. Supra n. 25.

30. Ontario Energy Board, "Reasons for Decision, In the Matter of the Ontario Energy Board Act and In the Matter of Potential Bypass of Local Gas Distribution Systems: E.B.R.O.410I, 411-I and 412-I" 12 December 1986.

31. Unreported, 26 March 1987, Toronto Divisional Court, Action No. 1243/86 (Ont. S.C.).

32. Supra n. 28.

33. British Columbia, Ministry of Energy, Mines and Petroleum Resources News Release, "Special Commissioner Appointed on Bypass Issue" 1987:24. 
This hearing has now been scheduled to take place in September of 1987 so that Mr. Millard can deliver his report prior to the end of the year. Specifically, Mr. Millard has been asked to look at the costs and benefits of the two proposals from the perspective not only of the applicants but also of Inland's other customers and, lastly, the local governments that now receive a franchise fee from Inland.

As a final point in this regard, it is noteworthy that the News Release announcing Mr. Millard's appointment also states that the Province's preferred solution is a negotiated one, whereby Inland would revise its tolls to keep these potential bypass customers on the Inland system. However, it remains to be seen if further hearings and, conceivably, litigation will occur in British Columbia.

\section{THE REVIEW OF THE BRITISH COLUMBIA NATURAL GAS SURPLUS DETERMINATION PROCEDURES}

As indicated in Section II of this paper, the October 31, 1985 Agreement committed the Province of British Columbia, along with the other signatories, to a review of its natural gas surplus determination procedures. On July 17, 1987, the Province announced the results of this review, whereby a new "Market-Based Formula" was established for evaluating future proposals for the use and removal of British Columbia's natural gas. $^{34}$

In order to fully understand the new Market-Based Formula it is necessary to have some appreciation of the legislative framework and the pre-existing tests.

In British Columbia, energy use in the province and the removal of energy from the province is governed by the Utilities Commission Act. ${ }^{35}$ Part 2 of this Act provides, inter alia, that an Energy Project Certificate ("EPC") is required for regulated projects in the province and that an Energy Removal Certificate ("ERC") is required for the removal of any energy resource from the province, subject to certain limited exceptions. These EPC's and ERC's are issued by the Minister of Energy, Mines and Petroleum Resources.

From 1981 to 1987, the British Columbia surplus determination procedures consisted of an Extended Reserves Test and two forms of Producibility tests. Basically, the former test protected a reserve equivalent to twenty-five times the current British Columbia annual total domestic requirement while the latter tests assessed the ability to actually produce sufficient quantities of natural gas, on an annual basis, to meet all existing needs as well as the proposed new energy project or energy removal.

Following the signing of the October 31, 1985 Agreement, the Province issued, in January, 1987, a "Discussion Paper Concerning British Columbia Natural Gas Surplus Determination Procedures and the British Columbia Energy Supply And Requirements Forecast $1984-2005$ " ${ }^{36}$

34. British Columbia, Ministry of Energy, Mines and Petroleum Resources, "B.C. Sets New Consumer Protection Rules for Natural Gas" 1987:33.

35. Supran. 28.

36. British Columbia, "Discussion Paper Concerning British Columbia Natural Gas Surplus Determination Procedures and the British Columbia Energy Supply and Requirements Forecast 1984 - 2005" (1987). 
This document invited interested parties to respond in writing to the numerous specific questions raised therein. A total of seventeen submissions were eventually received and circulated amongst all interested parties, who were then given an opportunity to provide additional comments. These submissions were then reviewed by the staff of the Ministry of Energy, Mines and Petroleum Resources.

In general, the submissions could be divided into two highly-polarized categories. Producers and producer associations proposed the elimination of any form of mandated surplus test and the adoption of a contractual basis of protection. On the other hand, the local distribution utilities and other consumer groups essentially advocated the retention, occasionally with minor amendments, of the existing procedures.

The Ministry of Energy, Mines and Petroleum Resources News Release describes the Market-Based Formula as a compromise between these two viewpoints. In essence, the Market-Based Formula involves a new Extended Reserves Test whereby there will be an allowance for domestic requirements equivalent to fifteen times the current annual consumption by the "core market" of residential, commercial and small industrial users. At the same time, the two Producibility tests have also been modified so that the principle focus will be on the ten year period following the commencement of the proposed new project or removal.

As described in the accompanying Reasons for Decision, ${ }^{37}$ the theory behind the new Market-Based Formula is that it should provide consumers in British Columbia with the level of protection that would exist naturally in a properly functioning marketplace. According to the Reasons for Decision, such a marketplace would be one in which distribution utilities would seek to provide approximately ten to fifteen years of contracted supply for their core customers. Since structural rigidities in the British Columbia marketplace may prevent this from happening naturally, the Market-Based Formula is intended to ensure that consumers have the same degree of security by way of mandated surplus procedures.

Obviously, the new British Columbia procedures are similar to those adopted by the Alberta Energy Resources Conservation Board, as set out in its recently released Report 87 - A, entitled "Gas Supply Protection for Alberta: Policies and Procedures". ${ }^{38}$ Both involve tests which reserve fifteen times the annual core market consumption and both will result in significant new volumes of natural gas being available for removal. However, it remains to be seen how these new tests will operate in practice and what the effect will be on the overall process of deregulation.

\section{CONCLUDING OBSERVATIONS}

As was noted at the outset of this paper and, hopefully, demonstrated herein, 1987 is a transitional year in the process of natural gas deregulation in British Columbia. A great deal is happening and the results of many of

37. British Columbia, "Review of the British Columbia Natural Gas Surplus Determination Procedures: Reasons for Decision" (1987).

38. Energy Resources Conservation Board, “Report 87-A: Gas Supply Protection for Alberta: Policies and Procedures" March 1987. 
the developments discussed in this paper are far from certain. Of course, the long term consequences of these changes are even harder to predict.

Undoubtedly, certain aspects of the natural gas industry, such as transportation and central processing, will have to continue to be regulated notwithstanding current trends in public policy. This is due to the plain fact that these involve natural monopolies, where market forces by themselves do not operate efficiently, or at all.

In addition, certain peculiar features of the British Columbia industry may necessarily imply that this Province should continue to take a more active role than other producing areas in ensuring the proper functioning of the marketplace. For example, the ratio between domestic production and domestic consumption is much lower in British Columbia than in Alberta. Therefore, the need for careful stewardship of a scarcer resource is arguably greater. Furthermore, the British Columbia production industry is unquestionably dominated by a relatively small number of very largevolume producers, again in contrast to the situation in Alberta. On occasion, this might well lead to distortions in market forces, thereby creating a further need for some form of limited intervention by the Province through its regulatory agencies, crown corporations or otherwise.

In summary, although the Province is on record as supporting the principle of deregulation of the natural gas industry, there are features of the situation in British Columbia which may make the process, and the result, somewhat different from that which occurs in the rest of Canada. Time will tell. 